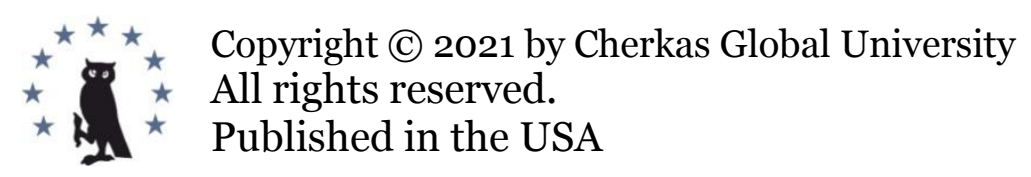

European Journal of Contemporary Education E-ISSN 2305-6746

2021. 10(4): $987-1002$

DOI: 10.13187/ejced.2021.4.987

https://ejce.cherkasgu.press

IMPORTANT NOTICE! Any copying, reproduction, distribution, republication (in whole or in part), or otherwise commercial use of this work in violation of the author(s) rights will be prosecuted in accordance with international law. The use of hyperlinks to the work will not be considered copyright infringement.

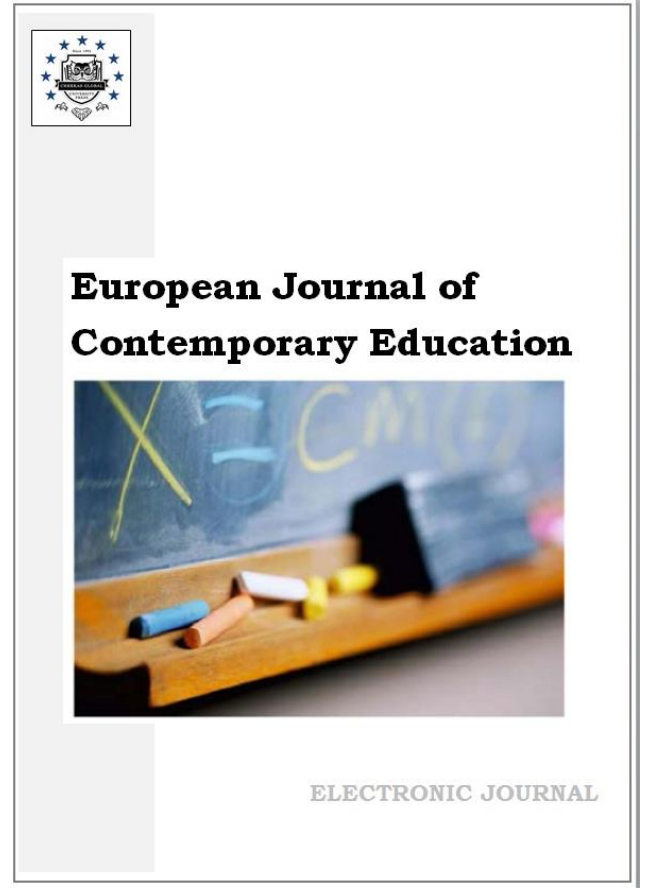

\title{
Applying Gamification in Learning the Basics of Algorithmization and Programming to Improve the Quality of Students' Educational Results
}

\author{
Elena V. Soboleva ${ }^{\text {a }}{ }^{*}$, Tatyana N. Suvorova a, Aleksandr V. Grinshkun ${ }^{\text {b, }}$ \\ Mikhail I. Bocharov ${ }^{c}$ \\ a Vyatka State University, Kirov, Russian Federation \\ b Moscow City University, Moscow, Russian Federation \\ ${ }^{c}$ Financial University under the Government of the Russian Federation (Financial University), \\ Moscow, Russian Federation
}

\section{Abstract}

The problem that the research is aimed at is caused by the need to use gamification methods and tools when studying the basics of algorithmization and programming for students to get the experience of communication with other people and artificial intelligence, big data analysis, and project management most demanded on the labor market.

The purpose of the study is to theoretically substantiate and experimentally test the effectiveness of gamification in learning the basics of algorithmization and programming to improve the quality of students' educational results.

The research methodology consists of the analysis and generalization of scientific works on the problems of gamification of learning and cognition processes, studying the basics of algorithmization. Empirical methods were used: observation, analysis of the results of work in the LogoWorlds program.

The results of the study. The paper clarifies the essence of the concept "educational results" and uses programming language tools to design a learning environment based on the principles of gamification, as much as possible focused on improving their quality. Specific materials are proposed that can be used to develop the ideas of gamification in the digital school, while justifying the need to study algorithmization and programming at all levels of education and training.

\footnotetext{
* Corresponding author

E-mail addresses: sobolevaelv@yandex.ru (E.V.Soboleva),tn_suvorova@vyatsu.ru (T.N. Suvorova), aleksandr@grinshkun.ru (A.V.Grinshkun), mi1@mail.ru (M.I. Bocharov)
} 
The conclusion summarizes the conditions under which gamification of learning the basics of algorithmization and programming is most effective for improving the quality of schoolchildren's academic achievements.

Keywords: program code, instrumental environment, LogoWorlds, thinking development, demanded skills, digital society.

\section{Introduction}

\subsection{Relevance of the problem}

The relevance of the presented research is due to the following factors:

1. The field of online education is developing very rapidly in modern sanitary and epidemiological conditions. Along with the familiar graphic and text editors, cloud technologies, and interactive presentations, the approaches of micro-learning, m-learning, and gamification are being introduced into the educational process (Soboleva et al., 2017).

E.S. Samoylova believes that unduly theoretical systems of distance education and formal tests should be replaced by a conscious activity while interacting with a computer, solving practiceoriented tasks (Samoylova, 2020). E.A. Nikitskaya, E.O. Gladysheva, V.S. Sokolova specify that the teacher of a digital school should strive to create favorable conditions for scholchildren to learn. Students should effectively and jointly build up the skills and competencies demanded by society (Nikitskaya et al., 2020). According to A.V. Maltseva, A.V. Tomiltseva, in the future, the labor market will not evaluate the knowledge and skills of school-leavers, but the results of their work. This approach will allow us to link the requirements of the education system with the requirements of the state and business, and to assess the real effect of training (Maltsev, Tomiltsev, 2017).

L.R. Murillo-Zamorano et al. determine that gamification services have a powerful didactic potential to support schoolchildren at all stages of their cognitive, career-oriented activities (Murillo-Zamorano et al., 2021). Moreover, experts predict that in the future, learning based on the principles of gamification will go beyond e-courses and become an integral, organic part of the educational process (Legaki et al., 2021).

Thus, the trends in the development of e-education, the requirements of the state, society and business to the level of skills and competencies of school-leavers determine the relevance of the issues of gamification of learning and cognition.

2. Programming skills, competencies in the field of artificial intelligence, data analysis are among the most popular, according to L.B. Tarenko, on the job exchange of the present and future (Tarenko, 2021). Moreover, programming by its structure involves continuous training and improvement of such skills as working with information, managing in conditions of uncertainty, interacting with groups of people and technical devices. All these competencies are not only part of the soft skills system, but also provide a certain level of academic achievement for students (Kashpur et al., 2020). At the same time, learning the basics of algorithmization and programming is a complex and time-consuming process, which often causes negative psychological reactions of students (stress, fear of mistakes, the need to memorize constructions, theory). Many teenagers of the "generation $Z$ " are excellent at brain-teasers, puzzles, computer games, robots, but they cannot make their own algorithm (Nikitskaya et al., 2020).

The use of gamification technology will not only minimize negative emotional stress, but also support the study of fundamental theoretical concepts and basic algorithmic constructions in a gamified way (Soboleva et al., 2018). In other words, including game elements in the educational and cognitive activity on writing programs contributes to acquiring general academic and subjectspecific knowledge and skills, forming soft skills, collaboration and creativity, and the development of thinking (Papert, 1993).

3. Despite the fact that the use of game elements in the classroom is welcomed and actively used by teachers in the digital school, they are mainly used separately for motivation, reflection, and stress relief (Manzano-León et al., 2021). Obviously there are not enough holistic methodological systems that involve game mechanics at all stages of the lesson. This is especially true for learning and fixing new material. The system of traditional classroom education will have to change to meet the needs of a new, more comprehensive approach to education and the development of the student's personality. As a result, it is the teacher in the digital school who will be responsible for integrating game mechanics into the classroom (Cheng et al., 2021). Only such methodological work will allow gamification to fit seamlessly into a single information educational 
space. According to H. Hossein-Mohand et al., it may not even be a single gaming platform, but several perfectly integrated gamification resources that will provide the student with an individual user experience (Hossein-Mohand et al., 2021).

Thus, there is a practical need to apply gamification in learning the basics of algorithmization and programming in order to provide students with the experience of communication with other people and artificial intelligence, big data analysis, and project management that is most demanded on the labor market. The effective organization of the corresponding cognitive activity is determined by the capabilities and skills of the teacher of the digital school.

\subsection{Goals and objectives of the research}

The aim of the study is determined by the need to implement didactic possibilities of gamification technology to improve the quality of students' educational results.

Objectives of the study:

- to clarify the essence of the concept "educational results" in the context of informatization processes and the requirements of society for modern school-leavers;

- to describe the didactic potential of gamification technology for students to gain experience in communication with other people and artificial intelligence, big data analysis, and project management that is in demand on the labor market;

- to design a learning environment based on the principles of gamification, which is maximally focused on improving the quality of students' educational results;

- to describe the areas of cognitive activity of schoolchildren in the development of game projects using the Logo programming language;

- to present the system of work of the participants of the didactic process on the game project when studying the basics of algorithmization and programming;

- to experimentally confirm the effectiveness of gamification methods and tools in learning the basics of algorithmization and programming to improve the quality of training.

\section{Discussion}

\subsection{Literature review}

The analysis of Russian and foreign scientific works on the problem of the research was carried out in two directions:

1) identification of the didactic potential of gamification to improve the quality of training, the formation of skills and competencies that are in demand in modern society;

2) generalization of the experience of organizing educational and cognitive activities to study the basics of algorithmization and programming.

\subsubsection{Analysis of Russian scientific and pedagogical literature}

The maturity of programming skills, communication with artificial intelligence and other people, and the level of cognitive development are the basic indicators that determine the effective didactic system (Soboleva et al., 2018). Within the framework of e-learning, digital technologies, gamification elements, cyber-physical devices, etc. are actively used to support the quality of learning. L.P. Varenina interprets the concept "gamification" as the application of game techniques in non-game situations (Varenina, 2014).

V. D. Shiryaev defines the essence of gamification as the application of game design methods for non-game areas, such as business processes, social projects, and training (Shiryaev, 2013). The introduction of gamification in the information environment of the school is primarily aimed at developing mobilization and activation of individual capabilities, personal creative fulfilment (Zamyatina, Abdykerov, 2015). N.I. Isupova, T.N. Suvorova points out that the game is characterized by the involvement of students in the game environment and the educational process, improvisation, competitive spirit, emotional component and satisfaction from cognitive activity (Isupova, Suvorova, 2019).

According to E.V.Soboleva, N.L. Karavaev, M.S. Perevozchikova, there are currently many computer services and online resources that can be used to organize the educational process aimed at implementing the principles of gamification (Soboleva et al., 2017). Clear, simple and convenient software tools allow you to create conditions for improving the quality of training. Including gamification elements, according to L.B. Tarenko, helps update the necessary knowledge, pre-test students' understanding of the topic under consideration, or consolidate the information received (Tarenko, 2021). At the same time, the resources of gamification allow to create additional 
cognitive stimuli due to their interactivity and adaptability to the modern realities of the digital world (Kashpur et al., 2020).

E.S. Samoylova supports their research and believes that gamification of education is designed to provide: the formation of knowledge, skills and abilities during the game process; monitoring of existing, acquired and developing personal qualities and educational results; solving combined tasks aimed at the formation and assessment of the formed supra-professional competencies (Samoylova, 2020).

L.P. Varenina reasonably concludes that computer games are the main form of entertainment for the modern generation (Varenina, 2014). At the same time V.D. Shiryaev formulates the position that gamification services can be used as a tool for motivation. It is obvious, in the author's opinion, that the mere existence of the game does not directly lead to an increased motivation and involvement in educational activities (Shiryaev, 2013). Therefore, according to the conclusions of A.V. Maltsev, A.V. Tomiltsev it is necessary to understand the conditions under which game elements can affect the qualitative improvement of educational results and personal development (Maltsev, Tomiltsev, 2017). Gamification, as noted by O.M. Zamyatina and Zh.S. Abdykerov, makes it possible to organize an effective transition from external motivation to play, i.e. from earning points, rewards and bonuses, to a more important internal motivation to learn (Zamyatina, Abdykerov, 2015). N.I. Isupova, T.N. Suvorova suggest using Kahoot!, Plickers, and Quizlet as the main resources for gamification (Isupova, Suvorova, 2019). In addition, gamification can serve as a tool for increasing the intensity of communication, involving students in interaction, teamwork, and creating their own information product (Soboleva et al., 2018).

At the same time, almost no attention is paid to programming tools. And this is a significant drawback of domestic research of the gamification essence, identifying the didactic potential of the technology. Although many of these works determine the significance of algorithmization for the intellectual development of the student (Soboleva et al., 2017; Tarenko, 2021). The innovative nature of L.B. Tarenko's ideas lies in the fact that the author suggests using gamification technology to train future programmers in terms of developing creative and analytical skills (Tarenko, 2021). And this position allows L.B. Tarenko to conclude that in the practical training, purposeful work on the formation and development of algorithmic thinking by means of gamification is necessary and should be of a systematic nature. For the effective formation and development of algorithmic thinking, according to E.A. Nikitskaya, E.O. Gladysheva, V.S. Sokolova, it is necessary to use a special system of tasks that should take into account the specifics of students' perception and thinking (Nikitskaya et al., 2020). Only in this case we can speak about modern information educational environment focused on the formation of a new style of thinking - thinking aimed at finding not just non-standard solutions, but strategically adjusted, suitable for use in the real world.

N.N. Rybka, studying the questions of society's gamification, concludes that this tendency is ambiguous, it creates numerous risks, negative aspects (Rybka, 2018). Through the game, you may not only perceive the world around you, but also influence it.

Among the few methodological developments, we note the study of N.N. Samylkina, A.V. Etova (Samylkina, Etova, 2020). The authors offer a practical version of applying gamification elements in learning the basics of algorithmization and programming in middle school. The authors use AppInventor as a software tool. Their choice is justified by the possibilities of this environment for visual programming, development of mobile applications. However, N.N. Samylkina, A.V. Etova do not use AppInventor specifically to study basic algorithmic constructs, to understand the principles of structural programming. Their version is maximally focused on the "clip" culture of "generation Z" teenagers' behavior. The paper focuses on the creation of a game project, rather than on the development of thinking with the resources of the software environment (Samylkina, Etova, 2020).

Thus, due to the fact that preparing students for self-development and personal selfdetermination, supporting their internal motivation for learning and purposeful cognitive activity are important tasks of the digital school, there is an objective need to apply the didactic potential of gamification resources within the framework of learning the basics of algorithmization and programming.

\subsubsection{Analysis of foreign studies}

Analytical work in this part of the study was also carried out in two directions. 
As part of the first direction, we note the work of L. R. Murillo-Zamorano et al., who study the possibilities of gamification to coordinate the demands of the state and business to the level of school-leavers' training, the standards of the educational system, the professional skills of teachers and the interests of students (Murillo-Zamorano et al., 2021). Scientists are testing the hypothesis that applying gamification does not only activate cognition, but also contributes to the development of the skills most demanded on the labor market of the XXI century, obtaining highquality education. The authors prove that in the educational process, the principles of gamification create additional conditions for joint creativity and acquisition of social experience.

Gamification uses game "thinking", i.e. the user of a gamified program, according to K. Skok, should perceive his activity as a kind of game (to be completely immersed in the game), and not a duty (Skok, 2016).

Z.R. Khan et al. determine that including gamification elements in the work on the educational project allows not only to successfully implement it, but also to understand the internal structure and connections between the implementation stages. The latter circumstance is important in cases where there is a need to plan and implement your own project (Khan et al., 2021). For the current research, these ideas are important because they are consistent with the principles of structural programming: splitting the problem into subtasks, performing each of them separately, assembling, checking the integrity and operability of the proposed solution (Papert, 1993).

N. Legaki et al. consider the possibilities of gamification to support decision-making, acquisition of forecasting skills in the conditions of the uncertain future (Legaki et al., 2021). Scientists prove that gamification tools can and should be used to model different scenarios of the situation development and stimulate the solution of cognitive problems.

Applying game functions to motivate students can fail if their initial motivation is too low. On the other hand, the internal motivation of players is determined by the need to belong, i.e. the ability to team up, the need to cooperate between characters with different skills or professions; to study the game content; to dominate and compete with other players or non-game characters (Manzano-León et al., 2021).

First, there is a lot of situationality in gamification. Therefore, according to M. Cheng, S. Su, and C. Kinshuk, in order to reveal the content of this concept, as well as to define the game, it is important to understand the goal of the developers, as well as to see the perception of the participants (Cheng et al., 2021).

Second, according to Y. Attali, M. Arieli-Attali, M. gamification uses game functions (elements, mechanics, frames, aesthetics, thinking, metaphors) in non-game situations (Attali, Arieli-Attali, 2015). It is the game activity that contributes to understanding and acceptance of the norms of information interaction in society, social conditions and practices.

Third, as C.-H. Su reasonably concludes, the term "gamification" can and should be used in relation to many aspects of activity: from everyday life (where boredom, repetition, and passivity are very common and where the desired type of behavior is to be encouraged), elementary operations, to complex processes of learning, development, and cognition ( $\mathrm{Su}, 2016)$. This is due to the universality and ubiquity of computer games and video games; the need to excite and maintain students' interest in learning in order to attract users and encourage them to achieve more ambitious goals, comply with the rules, and have fun (Hamza-Lup, Goldbach, 2021).

$\mathrm{H}$. Hossein-Mohand et al. investigate the educational potential of gamification in relation to the intellectual development of students at mathematics lessons (Hossein-Mohand et al., 2021). They proved that the exchange of information through online gaming spaces, creative activity and collaboration in implementing educational projects by means of digital technologies contributes to improving the quality of academic achievements.

M.C. Ramos-Vega et al. describe the experience of joint design of educational video games. Scientists prove that applying gamification supports the involvement of schoolchildren in the study of complex theoretical facts and patterns (Ramos-Vega et al., 2021).

Summarizing the analysis of the literature in the second direction, we conclude that most of the scientific and methodological works on the application of gamification for the study of programming are theoretical in nature (Batista et al., 2020). For example, I. Cetin, M.Y. Ozden, reasonably conclude that science rarely raises questions about the attitude of students themselves to cognitive activity when composing algorithms, writing programs. They proposed a scale for such an assessment (Cetin, Ozden et al., 2015). In addition, scientists prove that, despite the objective 
psychological difficulties, emotional stress, the successful solution of the problem by means of programming allows you to move to a qualitatively new level of knowledge.

G. Tisza, P. Markopoulos study directly the possibilities of gamification when working with program code (Tisza, Markopoulos, 2021). The importance of the conclusions of M.A. Kuhail, S. Farooq, R. Hammad, M. Bahja is that the authors raise the problem: how to organize programming activities, writing code for a visual game fascinatingly (Kuhail et al., 2021).

Thus, despite the fact that there are enough works devoted to gamification of learning and cognition, there are two important circumstances:

- in most of them, gamification tools are used only at one stage of the lesson (actualization, motivation, new material, fixing/systematization, control, reflection);

- the specifics of learning the basics of algorithmization and programming determine additional requirements for the choice of methods and means of gamification that meet the goals of personal development best.

\section{Materials and methods}

\subsection{Theoretical and empirical methods}

The following methods were used in the study: theoretical analysis and generalization of scientific literature on the problems of learning the basics of algorithmization in digital schools; the use of graphic possibilities of programming languages in cognition; the didactic potential of the LogoWorlds environment to support the cognitive activity of students.

The ideas of structural programming (the development of programs "top-down"; the division into subprograms, the use of basic algorithmic structures) are the basis for the cognitive activity of students. The stepwise refinement method is used for writing, debugging, and maintaining programs. The implementation of programming methods and tools when including game mechanics in training is supported by the following system of didactic principles: accessibility, consistency, connection of theory with practice, conscious activity, individual approach, cooperation. On the other hand, the programming technology is supported by the principles of gamification: the voluntary nature of the game, the algorithms of plot development as a reaction to the player's actions, logic and transitions between levels; a system of rewards, points, ratings, etc.

In addition, the organization of educational and cognitive activities of schoolchildren in the environment of LogoWorlds uses such methodological techniques of gamification as storytelling, thematic stages, the competitive nature of interaction, encouragement and motivation, and the openness of the participants' achievements in the game space. The interface approach in training is implemented due to the fact that the user is integrated into the information environment of the training system in a gamified way. To communicate with the objects of the environment, the student uses the menu, tools, work field, command field, and turtle forms.

To obtain up-to-date information about qualitative changes in the educational achievements of students, empirical methods were used: observation, analysis of the results of work in the LogoWorlds environment (user interface, game design, choice of algorithmic structures, etc.). The inclusion of gamification elements in learning the basics of algorithmization and programming was implemented in the course "Computer Science in games and tasks". This course is a part of extracurricular activities in the general intellectual direction of personal development in secondary school No. 11 in Kirov. To form the experimental and control groups, an entrance control event was organized, which included three tasks with levels of differentiation. Solving tasks involves working with ready-made program code of the LogoWorlds environment, modifying the algorithm and writing your own sequence of commands. In total, 48 students from the fifth and sixth grades took part in the experiment. The average age of the respondents was 11 years ( $51 \%$ of girls and $49 \%$ of boys).

The LogoWorlds application is used as a software tool for gamifying activities. This choice is justified by the fact that the application provides opportunities for purposeful development of students' thinking, communication with people and artificial intelligence, data analysis of various formats, and management of several objects (including graphical ones). At the stage of statistical processing, the $\chi_{2}$ (chi-square) Pearson test was used.

\subsection{The base of research}

The evaluation of the effectiveness of the proposed approach to gamification of learning the basics of algorithmization and programming to improve the quality of educational results of 
students was carried out in the course of a pedagogical experiment. 48 students from the fifth grade of school No. 11 in Kirov were involved. The average age of the respondents was 11 years (51 \% of girls and $49 \%$ of boys).

The sample was not random. To ensure conditions for group homogeneity, the same teacher conducted classes on the basics of algorithmization and programming for all students. He also formulated systems of educational tasks, directed information interaction in the process of solving tasks by students in the programming environment. Algorhythms were recorded in various ways (in particular, in a programming language) in the same classrooms, on the same hardware and software. The materials for the control work were developed by the authors in accordance with the current standard of basic general education.

\subsection{Stages of research}

The study was conducted in three stages.

At the preparatory stage of the experiment, the essence of the concept of "educational result" was clarified in the context of the informatization processes and the requirements of society for modern school leavers. The didactic potential of LogoWorlds tools for learning gamification is also studied. To evaluate the input conditions, the materials of a specially organized control event were used (the task of working with a ready-made algorithm for a specific performer, drawing up and implementing the algorithm, and modifying the algorithm).

As a result, the student could get 10 points for the correct solution of control tasks.

Thus, with the help of the control work materials, it was possible to collect the required initial data on 48 schoolchildren. Then the participants were divided: 24 in the experimental group, and 24 in the control group. The division is made in such a way that it is guaranteed that each group has the same measurable skills and qualities of the individual, their equal distribution.

Describing the sample, let us note that the experimental group consists of $51 \%$ of girls and $49 \%$ of boys.

The second stage of the study was devoted to the correlation of the topics in the course "Computer science in games and tasks" with the possibilities of the LogoWorlds programming environment. The sequence of sessions and the system of tasks for each of them were determined. Approximate titles for the final projects were formulated.

The third stage of the study covers experimental teaching and the use of gamification elements in teaching to improve the quality of shoolchildren's educational achievements.

\section{Results}

\subsection{Clarification of the essence of the basic concepts}

Let us formulate the characteristics of the gamification process in education, which reflect the authors' approach to the implementation of this phenomenon:

- the game is carried out taking into account the values set by the organizers;

- the game is always voluntary, i.e. the participants can stop it at any time;

- the rules of the game are very important;

- any action taken will affect in the future the game itself and the actions of other players;

- the game in training entails game didactics, i.e. game pedagogics;

- this is a training format that is built on a combination of game practice and pedagogical design;

- the game in training should always satisfy the principle of naturalness, its perception by students with pleasure.

We believe that to apply gamification in education, it is important to emphasize that the space of information interaction can be a desk game, a role-playing game, a virtual game, an imaginary world. As it will be proved further, the greatest didactic potential in terms of knowledge and personal development is the development of your own game space based on some software.

A list of skills was formulated that determine the level of educational achievements of students in accordance with the requirements of the current standard (Federal'nyj gosudarstvennyj obrazovatel'nyj..., 2010).

So, within the framework of the system of teaching the basics of algorithmization and programming, built on the principles of gamification, it is possible to assess the formation of the following educational results, which are manifested in: compliance with the norms and rules of behavior in the information interaction environment (game environment); participation in the 
discussion, promotion and testing of hypotheses, drawing up the algorithm; responsibility for the results of the algorithm and the actions of the formal performer; readiness and ability to make necessary changes to the algorithm and the program; readiness and ability to make a conscious choice of the trajectory of cognition, including the choice of the direction of development of the information interaction environment (the game world); the value-semantic attitudes of students formed by digital media (in particular, gamification resources).

Logo is a programming language designed for elementary and middle school students. This language is used when working in the LogoWorlds system. With a turtle or with any other character chosen by the student, it is faster to understand the basic logic of the programs, the interaction of characters. Teaching the Turtle any action leads students to comprehend their actions and thoughts. At the same time, the quality of education in general increases.

Using the tools of the Logo programming language, a learning environment based on the principles of gamification was designed, as much as possible focused on improving the quality of students ' educational results.

Under the educational results of the student in the framework of the presented research, we will understand not only the level of general academic and subject knowledge, skills and competencies, but also the level of development of thinking (system, critical, etc.), creative abilities (creativity), social activity.

\subsection{Educational and cognitive activities for developing game projects in the LogoWorlds environment}

The key idea of the proposed approach is that gamification of learning the basics of algorithmization and programming involves obtaining fundamental theoretical knowledge in computer science in a gamified way. Through the elements of gamification, not only introduction and presentation of educational material are changed, but also a positive emotional background is maintained, stress factors are minimized when developing an individual program.

Another important circumstance is that the most favorable conditions for implementing this approach arise at the level of the primary school or at the first stage of the middle one (5th-6th grade). At this age, the foundation is laid, which in the future will determine the personal style of thinking, the breadth and flexibility of the mind, the ability to independently form judgments. It is at this stage of training that the game organically combines with the educational and cognitive activities.

The game is a method of world cognition, guided by internal forces, that allows the student to master initial, but very important basics of the cultural behavior in society, in the team, in the family, in the virtual space in a short time (Batista et al., 2020). The game is not something imported from the outside, it supports cognition and intellectual education.

Programming, as proved by M.A. Kuhail et al., plays a special part in the development of student thinking, communication, social activity and creativity (Kuhail et al., 2021).

To achieve the goal of the study, there was developed a model an environment including the following components: a software tool (LogoWorlds application); principles and techniques of gamification; a methodology aimed at teaching programming. The Logo language, authored by S. Papert (1993), provides an opportunity to create objects that students can master independently, turning them into ways of understanding reality. When programming the actions of the Turtle, the student has to be aware of how he does it himself. By programming a computer, teenagers become aware of aspects of their own thinking. The effectiveness of such an environment is ensured by the fact that it:

- works in real time (there are no time delays between the student's action and the environment's reaction to this action);

- deals with dynamic models for solving specific practice-oriented problems;

- provides the conditions for processing cognition as a sequential ascent along a convergent spiral. This process simulates the stages of debugging a program, its sequential refinement.

The LogoWorlds application, integrating programming, allowed to use animation, graphics, and sound tools to implement game projects. All of the above, firstly, corresponds to the age and psychological characteristics of modern schoolchildren's thinking; secondly, it naturally complements the resources of gamification.

The content elements of learning in the developed environment are: the concept of the algorithm, the properties of the algorithm, the basic algorithmic constructions, variables and constants. It should 
be noted that the study of each topic is designed for several sessions (mastering new material, forming skills, choosing a topic for a game project, its development and defense).

The main attention is paid to the study of new theoretical knowledge, its meaningful application to solve the problem. Gamification resources were used to involve students in complex intellectual activities caused by the need to memorize, formulate, generalize, check, etc.). Usually, when students apply theoretical material to solve a problem, the computer is used for step-by-step assimilation of concepts, for performing exercises of various levels of difficulty, for receiving feedback during monitoring and evaluation. In a gamified learning environment supported by the Logo programming language, the traditional sequence is reversed: the learner himself controls and receives feedback. This is made possible by the fact that it is the student who programs the computer. With this approach, teenagers seize the initiative from artificial intelligence, stop being afraid of mistakes when composing algorithms. There is an introduction to research, creativity and independent discovery.

The training begins with an introductory material - a brief overview of the interface of the software tool. Further, students, analyzing their own, possibly previously acquired experience of using this tool (for example, in a study group, elective course) and their abilities, associate themselves with one of the proposed characters (Skipper the Penguin, Puss in Boots, Minion Dave). Then students receive the related instructions to create their first project in the LogoWorlds the classic Pong arcade game. The instructions are provided in three versions and are compiled according to the following principles:

1) if the student has chosen Minion Dave, then he receives detailed instructions for creating a game with hints on writing code for all the Turtles (initial level);

2) if the student has chosen Puss in Boots, then he receives less detailed instruction for creating a game with several hints on programming complex objects (basic level);

3 ) if the student has chosen the Skipper the Penguin, then he receives a short instruction without hints with a verbal description of steps to create the game (advanced level).

Participants, following the instructions received, design their own game world. The support of cognitive activity from the game teacher is implemented in accordance with the following conditions:

1) if the student has received an initial-level instruction, he is entitled to one clue;

2) if the student has received a basic level instruction, he is entitled to receive two clues;

3 ) if the student has received an advanced level instruction, he is entitled to receive three clues.

Students complete the first stage of introduction to the programming environment and receive a diploma of "Young Programmer".

The stage ends with reflection - students fill out questionnaires, which will allow the game teacher to assess their attitude to the lesson, the programming tool being studied, and the nature of the motivation for further study of the Logo. Based on the reflection materials, the teacher can compare the selected level and the achieved results for the diagnosis of students.

The second stage of introduction to the programming environment involves solving a system of problems on the following topics: "Movement and Drawing";"Appearance and Sounds"; "Procedures"; "Variables".

The proposed task systems are differentiated into the same levels as the received instructions (basic, intermediate, advanced levels). Students re-analyze their experience by answering the following questions: whether they correctly evaluated their abilities at the last lesson; whether they successfully completed the task; and choose one of the heroes (Skipper the Penguin, Puss in Boots, Minion Dave) to continue learning the basics of programming using the LogoWorld environment.

Thus, the developed approach based on the principles of gamification contributes to the individualization of learning, the design of the knowledge trajectory for each student, the analysis of opportunities and experience, the systematic diagnosis of the level of academic achievements, and the intensification of feedback. The elements of gamification and the chosen tool for learning the basics of programming increase the motivation of students, turn the educational process into an exciting journey, and contribute to improving the quality of educational results.

As an example of the final task, let us look at some of the game projects that support learning the basics of algorithmization and programming on the Logo. Figure 1 shows the working field, the user interface, the system of commands for the Turtles, which are the result of students' 
cognitive activity when implementing the "Race" algorithm. The game has a number of interpretation options: everyone chooses a Turtle, the choice of Turtles is a random number. Turtles can run in a straight line, in a circle. They can be two, four, etc. The essence of the game: the winner is the Turtle, which will advance the furthest.

The students ' interest was also aroused by the project "Wolf-Goat-Cabbage". In the game environment, it is required to transport a Wolf, a Goat, and a Cabbage by boat from one bank to the other. In so doing, a Wolf and a Goat, a Cabbage and a Goat cannot stay on the shore together at the same time. Students found it more attractive to implement an algorithm for a Lion, a Cow, and Grass.
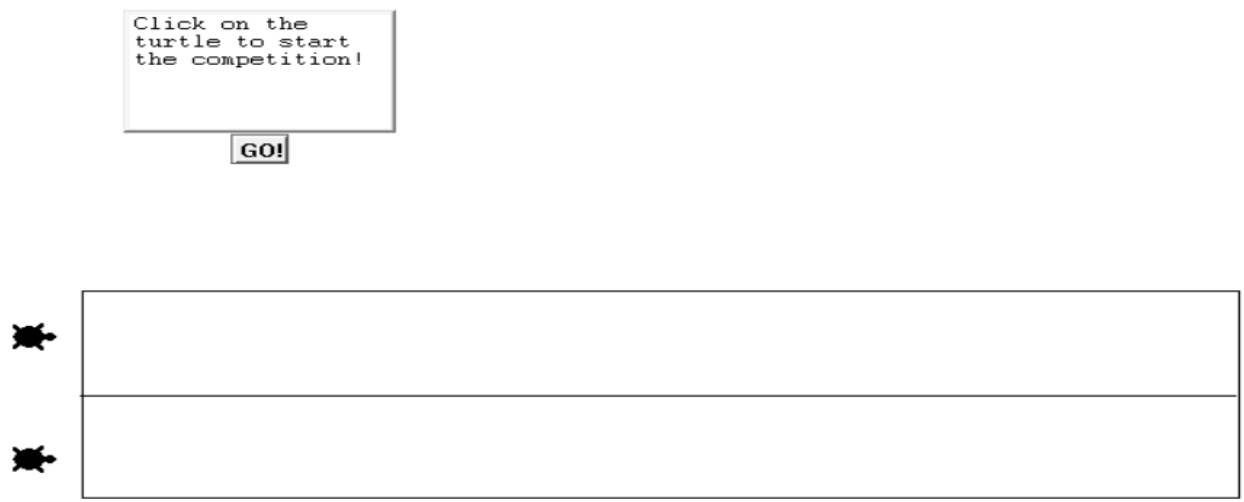

Fig. 1. An example of the game project in the Logo language

LogoWorld is not only a programming environment, but also a tool for modeling and research. Indeed, an important role in preparing a school-leaver who meets the challenges of the digital society is "learning through error". This is due to the fact that required soft skills include the ability to solve problems in conditions of uncertainty of the future. Debugging a program (finding and correcting errors in it) is often a time-consuming process. The Logo language greatly simplifies it. The solution is divided into many steps, each of which can be tested separately. If a mistake is made, the Turtle simply will not complete the task or will not perform it as it should. Students can find the error themselves, fix it, and run the program again. Students feel like researchers who are not afraid to create and make mistakes. It is especially important that they gain confidence in their abilities and can express their knowledge of the subject in a gamified way.

Due to the study of the Logo programming language, conditions were created for individual self-affirmation in the team, self-education, creating a situation of success, organizing research and group work.

Learning the basics of algorithmization in Logo-Worlds provides preliminary instruction in the basic concepts of computer science, the formation of programming skills, the development of thinking, activity and creativity. The selection of this particular software product allowed us to design an environment that allows us to study basic theoretical concepts, demonstrate the graphical capabilities of a computer, develop programming skills in an object-oriented environment, gain experience in independent research, collaboration and creativity, and fulfill the possibilities of gamification for self-realization, socialization and professional self-determination.

\subsection{Experimental evaluation}

\subsubsection{The ascertaining stage of the experiment}

At the first stage of the experiment, the materials of a specially organized control work were used to evaluate the input conditions. The requirements of the current federal standard of primary school for the educational results of school leavers, the fundamental concepts of algorithmization and programming, and the priorities of the digital society were taken into account.

1.1. The task for working with a ready-made algorithm. For example, there is an algorhythm written in the form of a flowchart (a proverb, a fragment of a song, etc.). Determine what will be in result. For the correct solution of the problem of this level, the student received 1 point.

1.2. A variant of the problem modification is to translate the algorithm presented in the school algorithmic language into a graphical way of writing. For the correct solution of the problem of this level, the student received 2 points. 
1.3. Another complexity is that an algorithm is given to a specific performer.

The performer NickName goes on a trip to the campus of the Vyatka State University. When moving he leaves a trace in the form of a straight line. The performer has the following commands:

1. Move to the vector $(a, b)$ - the performer moves to the point that can be reached from the given one by passing "a" units horizontally and "b" units vertically.

2. Entry: Repeat 5 [Command 1 Command 2] - the sequence of commands in square brackets is repeated 5 times.

NickName is located at the library (at the origin). To implement NickName, an algorithm is formulated: shift by vector $(5,2)$; shift by vector $(-3,3)$; repeat 3 [shift by vector $(1,0)]$; shift by vector $(3,1)$. At what distance from the library will performer Nick-Name be located as a result of executing this algorithm? For the correct solution of the problem of this level, the student received 2 points.

Task 2. Students are required to write program code to solve a specific practical problem. For the correct solution of the problem of this level, the student received 2 points. For example, to draw up a plan for a personal plot, Arkady Petrovich needs to draw a circle that will represent a pond. Write a system of commands that will help him do this.

Task 3. Students are required to apply their existing programming knowledge in a new environment. For example, when printing the "smart home" model, Arkady Petrovich needs to draw the layout of the part for the design of the door turn. Write the appropriate command system. For the correct solution of the problem of this level, the student received 3 points.

So, for the correct solution of control tasks, the student could get maximum 10 points. Thus, it was possible to collect data on 48 students. When converting points to a quantitative scale, the following system was used: if the student scored less than 5 points, the mark was "unsatisfactory"; 5 or 6 points - "satisfactory"; if he received 7 or 8 points - "good"; in other cases, the mark was "excellent".

The sample was not random. As a result of the entrance control event, almost the same initial level of students' readiness to participate in the pedagogical experiment was revealed. From the total sample, experimental and control groups were formed (each of 24 students). The experimental group consisted of $51 \%$ girls and $49 \%$ boys.

\subsubsection{Forming stage of the experiment}

At the stage of the formative experiment, the teacher analyzed the requirements of modern society for training students in digital schools, the didactic possibilities of gamification resources and the potential of programming in the LogoWorld environment to form the required educational results.

The following components were identified in the structure of students' educational achievements:

- cognitive (a system of fundamental knowledge obtained in the process of learning based on the principles of gamification);

- activity-based (skills and abilities educational and cognitive activities);

- motivational-value-based (motivation for learning, positive attitude to the content of educational and cognitive activities, value orientations and interests);

- integrative (mastered key competencies).

In connection with the specified requirements to the level of educational results of middle school students, systems of tasks were formulated within each topic. For example, Bioethicist Vadim decided to participate in a scientific conference with a discovery in genetic modeling. According to the system of commands for the Turtle, determine which country Vadim represents. Or, the network doctor Vasily, in connection with the difficult epidemiological situation, noticed a pattern in his work: every day he receives three more clients over the network than the previous one. Vasily was interested in how many people he would consult in 6 days of work, if 56 people turned to him for help on the first day. Determine what will be the parameter and create an algorithm for solving the problem.

Next, the second stage of the study was devoted to the correlation of the topics of the course "Computer Science in Games and Tasks" with the possibilities of the LogoWorld programming environment. In particular, the sequence of sessions was determined:

1. Introduction to LogoWorld, the main commands of the Turtle, and the use of graphics.

2. Work with forms and text windows. Random number sensor. 
3. Creation of own game projects.

Approximate titles were formulated for game projects focused on the meaningful use of the Logo language tools to implement algorithms: "Wolf-Goat-Cabbage", Bache Algorithms, Tic-TacToe, Turtle Races, etc.

Further, classes were conducted in the control and experimental groups on the basics of algorithmization and programming. Students in the control group studied Logo programming according to the following scheme: introduction to LogoWorld (the simplest commands); procedures, Turtle shapes, loops, branching, text windows, lists. The introduction highlighted the advantages of using the Logo language. Each lesson is a complete independent topic, supported by material for additional reading, links to information resources. A sufficient number of examples, illustrations, and program codes were used, and tasks were proposed for self-solving. At the end of each session, the students completed a small test of 10 questions on the topic they had just studied.

\subsubsection{Control stage of the experiment}

At the fixing stage of the experiment, there was also a test. The types of tasks and the evaluation principles corresponded to the tasks and the procedure of the input test event.

Task 1. Vasily's brother, Andrian, studying in the specialty of Science-artist, received a course project. He is to develop a collection of paintings made by bacteria, glowing with different colors of fluorescent proteins.

1.1. To give a unified style to the future exhibition, the artist decided to develop a frame for each picture. Students are offered a ready-made algorithm in the Logo language. The task is to determine the type of framing.

1.2. The researcher was inspired by the regular shapes of the honeycomb (each individual honeycomb is a regular hexagon). He decided to use this drawing in his work as a layout. Friends found a model of a honeycomb for him on the Internet. Help Andrian implement this layout in the program code. But remember that materials from the Internet often contain errors. Turtle.

1.3. Modification of the task is that each side of the frame should be drawn by a separate

Task 2. Another art object, which, according to the artist, should take pride of place in the collection, is a well-known flower. Its seeds wonderfully reflect the aesthetics of regular forms in nature. He placed bacteria in a glass ball and, using a viscous medium that preserves the trajectory of their movement, obtained a picture. Run the code suggested for the Turtle and determine which flower you are talking about.

Task 3. Andrian decided to continue looking for regular geometric shapes in nature. He could see them in the sunflowers, or rather, in the way their seeds were arranged. "It would be nice if the bacteria drew these regular shapes in a Petri dish," the artist thought. Andrian made changes to the bacteria's DNA code that he thought would cause them to move in the desired direction to create a protein trace pattern. However, the result was the sunflower flowers themselves. However, this result satisfied the novice scientist. Write a program for a Turtle that draws a field of sunflowers. The clue: use several Turtles and two procedures (for drawing the flower head and stem).

Statistical analysis of the reliability of the results of the pedagogical experiment was evaluated using the $\chi^{2}$ (chi-square) Pearson test. The following hypotheses were accepted:

Ho: the quality of educational achievements in the experimental group does not differ statistically from the results of the control group.

H1: the quality of training in the experimental group is higher than that of the control group.

The results of the measurements before and after the experiment for the students of the control and experimental groups are presented in Table 1.

In an online resource (http://medstatistic.ru/calculators/calchit.html) the values of the criterion before $\left(\chi^{2}{ }_{\text {observ. } 1}\right)$ and after $\left(\chi 2_{\text {observ. } 2}\right)$ the experiment were calculated. For $\alpha=0.05$ according to the distribution tables, $\chi 2_{\text {crit }}$ is 7.815 . Thus, we get: $\chi 2_{\text {observ. } 1}<\chi 2_{\text {crit }}(0.16<7,815)$, and $\chi 2_{\text {observ. } 2}>\chi 2_{\text {crit }}(7,885>7,815)$. Consequently, the shift towards improving the quality of the educational results of the experimental group of students can be considered nonrandom. 
Table 1. The results of the test

\begin{tabular}{|c|c|c|c|c|}
\hline \multirow{2}{*}{ Rating scale } & \multicolumn{4}{|c|}{ The number of tested (people) } \\
\cline { 2 - 5 } & \multicolumn{2}{|c|}{$\begin{array}{c}\text { Experimental group } \\
\text { (24 students) }\end{array}$} & \multicolumn{2}{c|}{$\begin{array}{c}\text { Control group } \\
\text { (24 students) }\end{array}$} \\
\cline { 2 - 5 } & Before & After & 2 & 3 \\
\hline Excellent & 2 & 10 & 12 & 13 \\
\hline Good & 10 & 10 & 19 & 17 \\
\hline Satisfactory & 4 & 2 & 2 & Bfter \\
\hline Unsatisfactory & 8 & 2 &
\end{tabular}

Therefore, the shift towards increasing the maturity level of group creative thinking can be considered nonrandom.

\section{Discussion}

The sample of students was not probabilistic, therefore, experimental data cannot be generalized for the entire students population. The experimental and control groups were formed in such a way that it was guaranteed that each group had the same skills and personality qualities, and their equal distribution. The results of the input control event were taken into account for diagnostics.

The selection of participants for the experiment and the sample size are justified by the research specifics: learning the basics of algorithmization and programming, the didactic possibilities of gamification resources for learning, and the potential of the LogoWorld environment. Throughout the experiment, creative activity in the software environment was conducted by the same teacher, using the same software equipment in special classrooms.

After a quantitative analysis of the results obtained, we conclude that according to the results of the control event, $83 \%$ of the students of the experimental group received grades "good" and "excellent". According to the results of the input test, this value was equal to $50 \%$. The number of students who failed the task decreased from $33.3 \%$ to $8.3 \%$.

The dynamics of the results in the control group is not so significant. $50 \%$ of students received "excellent" and "good" grades. Initially, this indicator was equal to $45.8 \%$. The number of students who failed to complete the final test was $29.2 \%$ (compared to $33.3 \%$ in the input section).

In general, the pedagogical experiment allows us to conclude that the use of gamification in learning the basics of algorithmization and programming contributed to improving the quality of learning.

The results of the study correspond to the conclusions of S. Papert, one of the most authoritative scientists in the theory of knowledge and learning, about the didactic potential of the Logo programming language for the development of student thinking (Papert, 1993). The authors' conclusions of the given work confirm the previously obtained data on the effectiveness of gamification in programming training (Soboleva et al., 2018). In addition, the proposed version of including gamification elements in writing program code corresponds to the conclusions of modern foreign researchers G. Tisza, P. Markopoulos (Tisza, Markopoulos, 2021).

\section{Conclusion}

The study presents a solution to the problem caused by the need to use gamification methods and tools in learning the basics of algorithmization and programming for students to get the experience of communication with other people and artificial intelligence, big data analysis, and project management that is required in the labor market. Within the framework of the work presented, it was assumed and experimentally proved that the teacher needs to design a special gamified learning environment to solve the indicated problem.

In the course of the study, the following conditions were noted under which the gamification of learning the basics of algorithmization and programming is maximally effective for improving the academic achievements of schoolchildren:

1. Correlation of the educational goal and the results of gamification. First of all, before developing or using the game in the classroom, it is necessary to determine the goals and expected 
results: students should remember theoretical facts, get logically justified conclusions, write program code, develop a project based on the studied material. The goal will determine not only the content of the game space, but also the feedback mechanism. For example, students are suggested to develop a game project "Wolf-Goat-Cabbage". The teacher should specify which algorhythmic constructions should be used, which information resources should be employed.

2. Thinking through the plot of the game project. In order for complex theoretical material to be perceived, understood, remembered and applied in practice, the mentor should think through the story for the characters.

3. Mechanisms of user's interactivity and interaction with the environment. When designing the interface, you should provide various buttons and input windows. This is necessary for students to understand the importance of culture and norms of communication in the virtual space (convenience, simplicity, functionality).

4. Distribution of roles. LogoWorld resources support graphics, sound, animation, and programming. This means that the teacher gets an opportunity to divide the class into groups according to their interests, preferences, and abilities: to search information, to work out the interface and its design, to develop the code, to present and defend the project.

5 . Rules of the learning environment based on the principles of gamification. Students should understand how the game works: its rules and cause-and-effect relationships. For example, it is worth analyzing the conditions of the game "Wolf-Goat-Cabbage" not just in words, but in "reality". You can assign performers and, in fact, review for everyone all the commands of the algorithm step by step.

6. Assessment and educational achievements. In the presented learning environment, the mark for the implemented game space is not given. According to the results of defending game projects, students receive points, orders, diplomas. Alternatively, a rating of advanced players can be introduced (based on the implemented levels, the forms of the Turtle used, etc.). Awards reflect real educational achievements of students, but are not expressed in a quantitative scale. The assessment is based on the results of the test.

7. The chat to exchange experience, to assist in selecting algorithmic structures, testing the game levels.

8. Time limits (for example, using the game timer). This contributes to the formation of an important skill of working in conditions of limited resources.

The learning environment built on the principles of gamification contributes not only to the improved quality of the obtained subject and general academic knowledge, but also contributes to the development of thinking. During the development and implementation of the game project, soft skills that are in demand by the digital society are formed: planning, search, critical assessment and processing of information, collaboration, communication. All these skills are becoming essential for socialization in today's digital society.

Thus, the use of gamification in learning the basics of algorithmization and programming can improve the quality of students ' educational results.

The research materials can be used to develop the idea of gamification in the digital school, while justifying the need to study algorithmization and programming at all levels of education and training.

\section{References}

Attali, Arieli-Attali, 2015 - Attali, Y., Arieli-Attali, M. (2015). Gamification in assessment: Do points affect test performance? Computers \& Education, 83: 57-63. [Electronic resource]. URL: http://linkinghub.elsevier.com/retrieve/pii/So360131514002899 (data of access: 08.05.2021).

Batista et al., 2020 - Batista, A. F, Thiry, M., Gonçalves, R.Q., Fernandes, A. (2020). Using technologies as virtual environments for computer teaching: A systematic review. Informatics in Education. 19(2): 201-221.

Cetin, Ozden et al., 2015 - Cetin, I., Ozden, M.Y. (2015). Development of computer programming attitude scale for university students. Computer Applications in Engineering Education. 23(5): 667-672.

Cheng et al., 2021 - Cheng, M., Su, S., Kinshuk, C. (2021). Integrating smartphone-controlled paper airplane into gamified science inquiry for junior high school students. Journal of Educational Computing Research. 59(1): 71-94. 
Federal'nyj gosudarstvennyj obrazovatel'nyj..., 2010 - Federal'nyj gosudarstvennyj obrazovatel'nyj standart osnovnogo obshhego obrazovanija (utv. prikazom Ministerstva obrazovanija i nauki RF ot 17 dekabrja 2010 g. N 1897) [Federal State Educational Standard of Basic General Education (approved by the Order of the Ministry of Education and Science of the Russian Federation of December 17, 2010 N 1897)]. [Electronic resource]. URL: https://base.gara nt.ru/55170507/53f89421bbdaf741eb2d1ecc4ddb4c33/

Hamza-Lup, Goldbach, 2021 - Hamza-Lup, F.G., Goldbach, I.R. (2021). Multimodal, visuohaptic games for abstract theory instruction: Grabbing charged particles. Journal on Multimodal User Interfaces. 15(1): 1-10.

Hossein-Mohand et al., 2021 - Hossein-Mohand, H., Trujillo-Torres, J-M., GómezGarcía, M., Hossein-Mohand, H., Campos-Soto, A. (2021). Analysis of the use and integration of the flipped learning model, project-based learning, and gamification methodologies by secondary school mathematics teachers. Sustainability (Switzerland). 13(5): 1-18.

Isupova, Suvorova, 2019 - Isupova, N.I., Suvorova, T.N. (2019). Gejmifikacija uchebnogo processa s ispol'zovaniem tehnologii" perevernutyj klass" [Gamification of the educational process using the "flipped classroom" technology]. Perspektivy nauki $i$ obrazovanija. 5(41): 412-427. [in Russian]

Kashpur et al., 2020 - Kashpur, B.B., Gubanov, A.B., Feshchenko, A.B., Izofatova, M.S., Kobenko, A.B. (2020). Vzaimosvjaz' obrazovatel'nyh dostizhenij starsheklassnikov i ih cifrovogo sleda v social'noj seti [Correlation between academic achievements of high school students and their digital shadow in social network]. Pedagogika $i$ prosveshhenie. 4: 37-51. [Electronic resource]. URL: https://nbpublish.com/library_read_article.php?id=33952 [in Russian]

Khan et al., 2021 - Khan, Z.R., Dyer, J., Bjelobaba, S., Gomes, S.F., Dlabolová, D.H., Sivasubramaniam, S., Harish, P. (2021). Initiating count down - gamification of academic integrity. International Journal for Educational Integrity. 17(1): 1-15.

Kuhail et al., 2021 - Kuhail, M.A., Farooq, S., Hammad, R., Bahja, M. (2021). Characterizing visual programming approaches for end-user developers: A systematic review. IEEE Access. 9: 14181-14202.

Legaki et al., 2021 - Legaki, N, Karpouzis, K, Assimakopoulos, V., Hamari, J. (2021). Gamification to avoid cognitive biases: An experiment of gamifying a forecasting course. Technological Forecasting and Social Change. 167.

Maltsev, Tomiltsev, 2017 - Maltsev, A.B., Tomiltsev, A.B. (2017). Monitoring kachestva uchebnyh dostizhenij: predmet, funkcii, metody [Monitoring of quality of educational achievements: subject, functions, methods]. Vysshee obrazovanie $v$ Rossii. 5 (212): 23-33. [Electronic resource]. URL: https://www.elibrary.ru/item.asp?id=29154954 [in Russian]

Manzano-León et al., 2021 - Manzano-León, A., Camacho-Lazarraga, P., Guerrero, M. A., Guerrero-Puerta, L., Aguilar-Parra, J.M., Trigueros, R., Alias, A. (2021). Between level up and game over: A systematic literature review of gamification in education. Sustainability (Switzerland). 13(4): 1-14.

Murillo-Zamorano et al., 2021 - Murillo-Zamorano, L.R., López Sánchez, J.A., Godoy-Caballero, A.L., Bueno Muñoz, C. (2021). Gamification and active learning in higher education: Is it possible to match digital society, academia and students' interests? International Journal of Educational Technology in Higher Education. 18(1): 1-27.

Nikitskaya et al., 2020 - Nikitskaya, E.A., Gladysheva, E.O., Sokolova, V.S. (2020). Problemy obrazovatel'nogo processa pokolenija Z [Problems of the educational process of generation Z]. Innovacii $v$ obrazovanii. 1: 12-17. [Electronic resource]. URL: https://www.elibrary.ru/item .asp?id=41868701 [in Russian]

Papert, 1993 - Papert, S. (1993). Mindstorms: children, computers, and powerful ideas. New York: Basic Books, 230 p.

Ramos-Vega et al., 2021 - Ramos-Vega, M.C, Palma-Morales, V.M., Pérez-Marín, D., Moguerza, J.M. (2021). Stimulating children's engagement with an educational serious videogame using lean UX co-design. Entertainment Computing. 38.

Rybka, 2018 - Rybka, N.M. (2018). Igraizacija i opyt ispol'zovanija komp'juternyh igr v prepodavanii filosofii $\mathrm{v}$ tehnicheskih uchrezhdenijah vysshego obrazovanija [Gamification and experience of using computer games in teaching philosophy in technical institutions of higher 
education]. Informacionnye tehnologii $i$ sredstva obuchenija. 67. (5): 213-225. [Electronic resource]. URL: https://www.elibrary.ru/item.asp?id=36762541 [in Russian]

Samoylova, 2020 - Samoylova, E.S. (2020). Formirovanie informacionnoj kul'tury mladshego shkol'nika sredstvami igrovyh tehnologij v distancionnom obuchenii [Formation of the information culture of a primary student by means of gaming technologies in distance learning]. Kazanskij pedagogicheskij zhurnal. 5(142): 169-176. [in Russian]

Samylkina, Etova, 2020 - Samylkina, N.N., Etova, A.B. (2020). Sozdanie mobil'nyh prilozhenij v MIT App Inventor $\mathrm{s}$ ispol'zovaniem jelementov gejmifikacii pri izuchenii programmirovanija $\mathrm{v}$ osnovnoj shkole [Creating mobile apps in Mit App Inventor using gamification elements when learning programming in basic school]. Informatika $v$ shkole. 8: 37-45. [in Russian]

Shiryaev, 2013 - Shiryaev, V.D. (2013). Gejmifikacija kak sposob motivacii [Gamification as a way of motivation]. Sovremennaja nauka: aktual'nye problemy i puti ih reshenija. 5: 24-26. [in Russian]

Skok, 2016 - Skok, K. (2016). Gamification in education - practical solutions for educational courses. Polish Journal of Applied Psychology. 14 (3): 73-92.

Soboleva et al., 2018 - Soboleva, E.V., Galimova, E.G., Maydangalieva, Z.A., Batchayeva, K.K. (2018). Didactic value of gamification tools for teaching modeling as a method of learning and cognitive activity at school. Eurasia Journal of Mathematics, Science and Technology Education. 14(6): 24272444. DOI: https://doi.org/10.29333/ejmste/89843 (date of access: 01.03.21).

Soboleva et al., 2017 - Soboleva, E.V., Karavaev, N.L., Perevozchikova, M.S. (2017). Sovershenstvovanie soderzhanija podgotovki uchitelej k razrabotke i primeneniju komp'juternyh igr v obuchenii [Improving the content of teacher training for the development and application of computer games in learning process]. Vestnik Novosibirskogo gosudarstvennogo pedagogicheskogo universiteta. 7 (6): 54-70. DOI: http://doi.org/10.15293/2226-3365.1706.04 [in Russian]

Su, 2016 - Su, C.-H. (2016). The Effects of Students' Learning Anxiety and Motivation on the Learning Achievement in the Activity Theory Based Gamified Learning Environment. EURASIA Journal of Mathematics, Science and Technology Education. 13 (5): 1229-1258. DOI: http://doi.org/10.12973/eurasia.2017.00669a (data of access: 13.11.2019).

Tarenko, 2021 - Tarenko, L.B. (2021). Gejmifikacija processa podgotovki budushhih programmistov kak sposob formirovanija kreativnyh analiticheskih umenij [Gamification of the process of future programmers' training as a method for forming creative analytical skills]. Perspektivy nauki. 1(136): 122-125 [Electronic resource]. URL: https://www.elibrary.ru/item. asp?id=45089808 [in Russian]

Tisza, Markopoulos, 2021 - Tisza, G., Markopoulos, P. (2021). Understanding the role of fun in learning to code. International Journal of Child-Computer Interaction. 28: 1-10.

Varenina, 2014 - Varenina, L.P. (2014). Gejmifikaciya v obrazovanii [Gamification in education]. Istoricheskaya i social'no-obrazovatel'naya mysl'. 6-2 (28): 314-317. [in Russian]

Zamyatina, Abdykerov, 2015 - Zamyatina, O.M., Abdykerov, Zh.S. (2015). Formirovanie i ocenka kompetencij obuchayushchihsya putem gejmifikacii obrazovatel'nogo processa [Development and assessment of students' competences through gamification of education]. Koncept: nauch.metod.ehlektron. zhurn. 15: 26-30. [Electronic resource]. URL: http://e-koncept.ru/2015/95147.htm [in Russian] 